\title{
The Presumption of Resulting Trust AND BENEFICIARY DESIGNATIONS: WHAT'S INTENTION GOT TO DO WITH IT?
}

\author{
JASON M. CHIN, ARCHIE RABINOWITZ, \\ AND AOIFE QUINN*
}

\begin{abstract}
When opening an RRSP or RRIF, investors typically designate a beneficiary. We expect that when making this choice, most investors intend that their designated beneficiary will indeed benefit from the investment on their death. If there is a dispute between the designated beneficiary and the investor's estate, we further expect investors intend that their choice of beneficiary will prevail. Surprisingly, this is not the case in many provincial appellate courts, which in fact favour the estate in such disputes. More specifically, most Canadian courts apply the presumption of resulting trust to beneficiary designations: they assume, absent other evidence, that the designated beneficiary holds the proceeds of the RRSP or RRIF in trust for the deceased investor's estate. Only Saskatchewan has taken a contrary position. The Alberta Court of Queen's Bench in Morrison Estate (Re) recently weighed both options and endorsed the approach that applies the presumption of resulting trust.
\end{abstract}

In this article, we analyze the doctrine of resulting trust, its rationale as presented by several leading cases, and empirical evidence evaluating the intentions of Canadian investors. We conclude that applying the presumption of resulting trust to beneficiary designations betrays both the theory and purpose of the presumption. It also runs counter to the intentions of most Canadians and creates uncertainties in millions of beneficiary designations. Finally, we present several solutions for bringing the law in line with the intentions of investors and, indeed, common sense.

\section{TABLE OF CONTENTS}

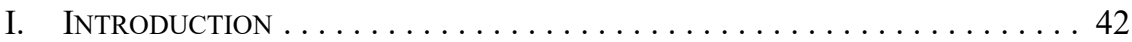

II. The Resulting Trust and Equitable Presumptions . . . . . . . . . . 43

III. The Purpose of the Presumptions $\ldots \ldots \ldots \ldots \ldots \ldots \ldots \ldots \ldots \ldots . \ldots \ldots$

A. The Intentions of the Transferor . . . . . . . . . . . . 44

B. Holders of the Evidence ANd Managers of Assets $\ldots \ldots \ldots . .48$

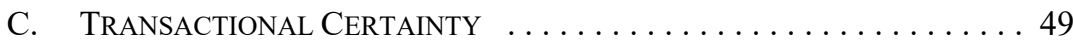

IV. THE APPLICATION OF THE PRESUMPTION OF RESUlting TRUST

TO BENEFICIARY DESIGNATIONS $\ldots \ldots \ldots \ldots \ldots \ldots \ldots \ldots \ldots \ldots . \ldots . \ldots 49$

A. Saskatchewan: The Presumption of Resulting Trust

Does Not Apply to Beneficiary Designations . . . . . . . . . . 50

B. The Presumption of Resulting Trust

APPLIES TO BENEFICIARY DESIGNATIONS $\ldots \ldots \ldots \ldots \ldots \ldots \ldots$

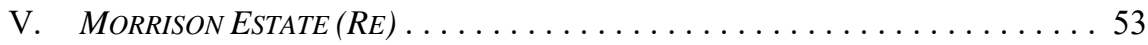

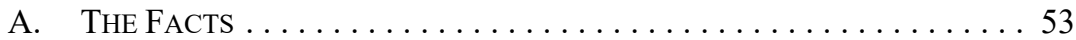

B. Should the Presumption of Resulting Trust

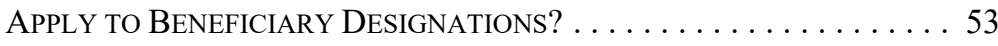

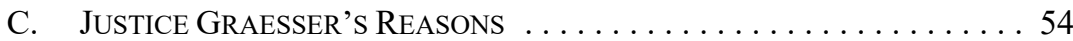

Jason M Chin, Adjunct Professor, University of Toronto Faculty of Law; Associate, Dentons Canada LLP, Toronto. Archie Rabinowitz, Partner, Dentons Canada LLP, Toronto. Aoife Quinn, Articling Student, Dentons Canada LLP, Toronto. The authors heartily acknowledge the gracious support of Ian Colvin, research librarian. 
VI. The PRESUMPTION OF Resulting TRUst

Should Not Apply to Designated Beneficiaries $\ldots \ldots \ldots \ldots \ldots . \ldots 56$

A. THE INTENTION OF THE TRANSFEROR $\ldots \ldots \ldots \ldots \ldots \ldots \ldots$

B. AN EMPIRICAL EXAMINATION OF DONATIVE INTENT

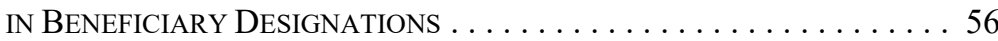

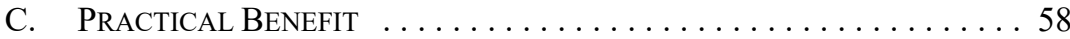

D. TRANSACTIONAL CERTAINTY $\ldots \ldots \ldots \ldots \ldots \ldots \ldots \ldots \ldots$

E. RE SCOTTISH EQUITABLE IS PER INCURIAM . . . . . . . . . . . . . 59

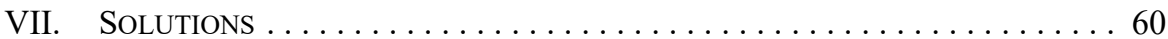

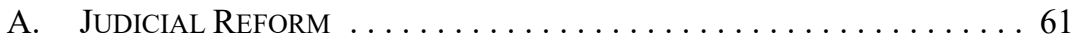

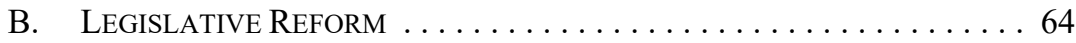

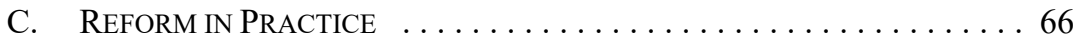

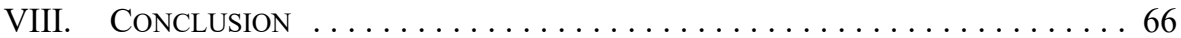

APPENDIX A: EMPIRICAL STUDY $\ldots \ldots \ldots \ldots \ldots \ldots \ldots \ldots \ldots \ldots \ldots \ldots$

\section{INTRODUCTION}

When opening Registered Retirement Savings Plans (RRSPs) and Registered Retirement Income Funds (RRIFs), investors have a decision to make. They are asked to designate a beneficiary - typically their spouse, family member, or estate. This person or entity receives the proceeds of the investment when the registered investor dies. It is an important and, on its face, simple decision. We believe - and provide empirical evidence supporting our belief - that when making this decision, investors intend that their designated beneficiary will receive the proceeds of their RRSP or RRIF on their death, and further expect the law will respect this stated intention. A line of English and Canadian cases has held otherwise. These cases, culminating in Morrison Estate (Re), ${ }^{1}$ a recent decision of the Alberta Court of Queen's Bench, pose a serious problem to millions of RRSP and RRIF beneficiaries and cut to the heart of resulting trust law in Canada and England.

Morrison, relying on a poorly understood and conflicting line of English and Canadian cases, held that the presumption of resulting trust applies to beneficiary designations. This means that, absent other considerations, designated beneficiaries will not benefit from the RRSP or RRIF. Instead, the designated beneficiary holds the proceeds on trust for the estate. This issue is exacerbated by the Supreme Court of Canada's decision in Pecore v. Pecore. ${ }^{2}$ Pre-Pecore, beneficiary designations from parents to their adult children were presumed gifts and thus not subject to the presumption of resulting trust. Pecore, however, eliminated the presumption of advancement to adult children. As a result, these adult children may be at serious risk of losing their RRSP and RRIF entitlements.

In this article we suggest that the view in Morrison and the cases it draws on represent an illogical application of the resulting trust doctrine. The law of resulting trust is devoted to respecting the intentions of transferors. Therefore, applying the presumption of resulting trust to beneficiary designations betrays this purpose in a manner that is theoretically unsound and dangerous to millions of investors. Moreover, applying the presumption of resulting trust to 
beneficiary designations carries none of the pragmatic and evidentiary benefits that have been associated with the presumption. With millions of Canadians contributing billions of dollars into RRSPs each year, ${ }^{3}$ the issues raised in Morrison have serious implications for a great number of beneficiaries.

In supporting the above conclusions, we first review resulting trusts and the presumptions that give rise to and avoid them. We then discuss the operation of the presumptions in the context of designated beneficiaries in four Canadian provinces and England, which sets the stage for Morrison. We go on to review Morrison and suggest that its holding, and the Canadian position in general, fails to give effect to the intentions and expectations of most Canadians. To support this point, we present original empirical data suggesting that RRSP investors intend their designated beneficiaries to receive the proceeds of the RRSP on their death, rather than their estate. Finally, we conclude with solutions that will protect designated beneficiaries and help ensure investors' intentions are respected.

\section{The Resulting Trust and Equitable Presumptions}

Resulting trusts generally arise in two scenarios: when an express trust fails, and when a gratuitous transfer has been made. ${ }^{4}$ In both scenarios, "someone has received an asset at the expense of another person and the trust causes the beneficial ownership of that asset to be returned to that other person." This article is concerned with the second variety: resulting trusts that come about because of gratuitous transfers. This type of trust has vexed both courts and academics for several reasons, including the uncertainty surrounding the role of intention in bringing about the trust, and whether its operation is purely anachronistic or if it can be justified in modern times. ${ }^{6}$

Gratuitous transfer resulting trusts operate on the basis of equitable presumptions: on the execution of a gratuitous transfer, there is a presumption of a resulting trust. Equity assumes bargains (rather than gifts), ${ }^{7}$ and thus presumes that the recipient holds the asset in resulting trust for the transferor. Presently, there are two theoretical accounts concerning the manner in which the transferor's intentions impact the operation of the presumption of resulting trust. We discuss these two accounts in the following section, "The Intentions of the Transferor." The presumption of advancement represents an opposing force, preventing the presumption of resulting trust from arising. It is based on the nature of the relationship between the transferor and recipient, and causes the court to presume the transferor intended a gift. The onus thus shifts from recipient to transferor, who must adduce evidence that a gift was not intended. If such evidence is adduced, beneficial ownership of the asset results back to the transferor. Both the categories of relationship that give rise to the presumption of

3

Statistics Canada, "Table 1 Registered Retirement Savings Plan Contributors: Canada, Provinces and Territories"'(13 February 2015), online: <www.statcan.gc.ca/daily-quotidien/150213/t150213b001-eng. htm>.

4 Robert Chambers, "Resulting Trusts in Canada" (2000) 38:2 Alta L Rev 378 at 383-87 [Chambers, "Resulting Trusts"]; Donovan WM Waters, Mark R Gillen \& Lionel D Smith, eds, Waters' Law of Trusts in Canada, 4th ed (Toronto: Carswell, 2012) at 397-98. Chambers, "Resulting Trusts," ibid at 382.

See ibid at 393-95; Robert Chambers "The Presumption of Resulting Trust: Nishi v. Rascal Trucking Ltd." (2014) 51:3 Alta L Rev 667 at 670-73; CD Freedman, "Reassessing Gratuitous Transfers by Parents to Adult Children" (2005) 25 Est Tr \& Pensions J 174; William Swadling, "Explaining Resulting Trusts," (2008) 124:1 Law Q Rev 72.

Waters, Gillen \& Smith, supra note 4 at 405-408. 
advancement and the rationale that underlies the selection of these categories have been subject to a great deal of debate.

Traditionally, the presumption of advancement applied to transfers from husband to wife and from father to child. The Supreme Court of Canada in Pecore both expanded and contracted the presumption of advancement. In terms of expansion, the Court held that the presumption applies to transfers not only from father to child, but also from mother to child. ${ }^{8}$ As discussed below, this expansion of the doctrine flows from the notion that both mothers and fathers have a moral obligation to support their children, and are thus equally likely to intend gifts. In terms of contraction, the Supreme Court of Canada eliminated the presumption of advancement between parents and adult children because the moral obligation to assist one's child is mostly gone once the child reaches adulthood (and indeed, may reverse when the parent reaches a certain age). ${ }^{9}$ Courts and commentators have remarked that the equitable presumptions are outdated and that the circumstances they arose from have long passed. Still, courts have refrained from abolishing or further limiting the presumptions, noting they still have a role to play in modern society. In the following section we review these purposes with a view to arguing that, while some of these purposes are sound and serve pressing demands in the context of gratuitous transfers, they play no such role when applied to beneficiary designations.

\section{The Purpose of the Presumptions}

The presumptions of resulting trust and advancement play a variety of roles, some more controversial than others. First, the presumptions seek to give life to the intentions of the transferor. Second, they are pragmatic, facilitating the management of assets and placing the evidentiary burden on the party with greater access to evidence. Finally, they seek to promote transactional certainty.

\section{A. The Intentions of The Transferor}

Intention, in some form or another, is at the heart of the equitable presumptions. ${ }^{10}$ The role of intention is clearer with the presumption of advancement: the relationship between the parties operates as a proxy for intention when actual evidence of intention is thin or nonexistent. In this respect, the presumption is "a consensus of judicial opinion disclosed by reported cases as to the most likely inference of fact to be drawn in the absence of any evidence to the contrary." to son were, more likely than not, intended to be gifts, and thus treated them as such when no other evidence was available. The presumption of resulting trust has attracted a great deal more debate, ${ }^{12}$ which we discuss after a review of the presumption of advancement.

The presumption of advancement's foundation in intention ${ }^{13}$ is clear from both its origins and from its modern interpretation. With regard to the presumption as it applies between

\footnotetext{
Supra note 2 at para 33.

Ibid at paras 36,40 .

Rathwell v Rathwell, [1978] 2 SCR 436 at 451 [Rathwell].

Pettitt $v$ Pettitt (1969), [1970] AC 777 (HL (Eng)) at 823 [Pettitt].

See e.g. supra note 6.

See Freedman, supra note 6 at 191.
} 
husband and wife, Lord Reid in Pettitt surmised that it arose from the common practice of husbands giving gifts to their wives: "[I]t would seem that the judges who first gave effect to it must have thought either that husbands so commonly intended to make gifts in the circumstances in which the presumption arises that it was proper to assume this where there was no evidence."14

This presumption between husbands and wives has been abolished by statute in most provinces, and where it has not, it has been extremely limited by courts. ${ }^{15}$ The justification for this elimination and narrowing is largely that the presumption does not accord with the intent of transferors in modern society. Justice Dickson (as he then was) expressed this view in Rathwell: [T] he old presumption of advancement has ceased to embody any credible inference of intention."16

The presumption of advancement between parents and their children still operates, but has evolved with changes in the parent-child relationship. Notably, Waters suggests that the presumption initially did not apply to mothers because they lacked the financial resources of fathers and thus were less likely to intend any transfer to advance to the child. ${ }^{17}$ These cultural factors are no longer present, resulting in a change in the doctrine. Over time, courts $^{18}$ and commentators ${ }^{19}$ acknowledged that mothers are just as likely to intend a gift to their children. For instance, Justice Rothstein in Pecore stated that, as a result of cultural progress, women have the means and obligation to support their children and are thus "no less likely to intend to make gifts" ${ }^{20}$ as compared to fathers. The presumption now applies to transfers from mothers to their minor children.

Gifts to adult children no longer attract the presumption of advancement and this change in doctrine was also made by reference to presumed intent. As noted above, Pecore eliminated the presumption of advancement between parents and their adult children. The Supreme Court of Canada in Pecore focused on one justification for the presumption: a parent's moral obligation to support dependent children. The Supreme Court decided that this justification does not hold for adult children — parents do not intend a gift, but rather intend that their adult child will manage their assets for them. ${ }^{21}$

Justice Abella concurred in Pecore's result, but would not have narrowed the presumption of advancement. She reasoned that while the dependency justification may be less relevant for adult children, the justification of parental affection between parent and child endures into adulthood. In other words, a gift from a parent to their adult child is intended because parents naturally care about their children, young and old. ${ }^{22}$ C.D. Freedman has a similar view of the presumption, opining that parental affection is the "greatest indicator" 23 of intent in a transfer

Supra note 11 at 793 .

Waters, Gillen \& Smith, supra note 4 at $415-18$.

Supra note 10 at 452 .

Waters, Gillen \& Smith, supra note 4 at 418.

Wilson, Re (1999), 27 ETR (2d) 97 (Ont Ct J (Gen Div)) at para 50.

AH Oosterhoff et al, Oosterhoffon Trusts: Text, Commentary and Materials, 6th ed (Toronto: Carswell, $2004)$ at 575.

Supra note 2 at para 33.

Ibid at para 36.

Ibid at para 98 .

Freedman, supra note 6 at 196. 
between parent and child. While Justice Abella and Freedman disagreed with the majority of the Supreme Court of Canada in Pecore, all couched their reasons firmly in intent.

There are currently two competing views regarding intention's role in the presumption of resulting trust. Under the first (the "negative intent framework"), ${ }^{24}$ resulting trusts arise because the transferor did not intend to pass a beneficial interest. For example, assume A makes a gratuitous transfer of property to B. Absent other evidence and a relationship triggering the presumption of advancement, equity assumes that A did not intend to pass a beneficial interest in that property (that is, negative intent), and thus B holds it in resulting trust for A. Robert Chambers provides a useful explanation of the negative intent framework:

The presumption of resulting trust is an inference regarding the intention of an apparent donor. Proof of certain facts (that an apparent gift was made by someone who is not the parent or perhaps husband of the donee) leads the court to assume that another fact exists (that the apparent donor did not intend to make a gift). Unless disproved, equity responds to that lack of intention by compelling the donee to hold the apparent gift on resulting trust for the donor. ${ }^{25}$

Intent plays a different role under the second view (the "positive intent framework"). ${ }^{26}$ Here, the resulting trust arises because the transferor intended the transferee to hold the subject matter in trust. In terms of our example above, the positive intent framework would say that A held a positive intention from the outset that B would hold the property in trust for him or her. To understand this distinction, a brief historical note is useful.

The presumption of resulting trust can be traced back to a 15 th to 17 th century practice among English landowners to put title in their properties in the name of another person. This other individual would deal with the land for the use and benefit of the transferor (in other words a "feoffment of uses"). This arrangement conferred many advantages, including avoiding dowers and curtesys, allowing for more complex settlements of land, and avoiding forfeiture for treason. It became an extremely common practice.

As may be expected, it was often unclear when a "use" was created, as opposed to when an outright transfer occurred. This uncertainty gave rise to disputes, and the Chancellor found it was more convenient to put the onus of proof on the transferee because it is easier to prove an overt purchase for value than a "use." In other words, the Chancellor assumed a "use" in favour of the feoffor (that is, the transferor). Statutory reform eliminated uses, but courts applied the old rule by analogy to trusts: there was a presumption the transferor intended to create a trust in his or her favour. ${ }^{27}$

Proponents of the positive intent framework point to the historical underpinnings of the presumption, suggesting the rule should stay true to its origin and remain grounded in the intention to create a trust in one's own favour. Those in favour of the negative intent

Chambers, "Resulting Trusts," supra note 4; Peter BH Birks, "Restitution and Resulting Trusts" in Stephen Goldstein, ed, Equity and Contemporary Legal Developments (Jerusalem: Harry and Michael Sacher Institute for Legislative Research and Comparative Law, 1992) 335. 
framework are less interested in this appeal to history, noting instead that there are several resulting trust fact patterns that cannot be explained by positive intention. For example, a resulting trust can arise even when the transferor lacks the mental capacity to understand the nature of the transfer. ${ }^{28}$ In such cases, it is difficult to understand how a transferor lacking mental capacity could have intended to create a trust. ${ }^{29}$ Courts have not conclusively decided the matter, ${ }^{30}$ with several suggesting the presumption as a whole is anachronistic and overdue for reform. ${ }^{31}$

Under either the negative or positive intent framework, applying the presumption of resulting trust in the face of a beneficiary designation seems to thwart the intentions of the registered account holder. According to the negative intent framework, resulting trusts arise because there is no intention to pass a beneficial interest. However, when it comes to beneficiary designations, the act itself demonstrates a presence of intention to benefit the designated beneficiary. Indeed, the designator signs a form saying: I want a specific person to benefit when I pass away.

Recall that the positive intent framework suggests that resulting trusts arise because of the presumption that the transferor intended to create a trust benefiting him or herself. Under this framework, the mere act of beneficiary designation also seems to displace the presumption. In the case of beneficiary designations, the designating individual named another person or entity as beneficiary — they could not have simultaneously intended to set up a trust in their own favour. Thus, the presumption of resulting trust should not arise in either the negative or positive intent framework.

While we do not seek to resolve the longstanding tension between the negative and positive intent frameworks, we do note that the negative framework provides a more coherent structure for evaluating the role of intent in beneficiary designations. We find the negative framework more useful because we are interested in the intentions of lay investors, who likely do not intend to create a trust when designating a beneficiary. In other words, if the presumption of resulting trust applies to beneficiary designations, and we do not think it should, it is almost certainly not because these investors intended to set up a trust for their own benefit. This is simply not the way people think about their registered accounts.

On the other hand, there is a slight chance that these investors, when gratuitously designating a beneficiary, intended to retain some interest in the registered account. Later in this article, we will report evidence from a study in which we asked participants about whether they, as registered investors, intend to give absolutely or retain an interest for themselves and their estate. We chose not to ask our participants whether or not they

Goodfellow v Robertson (1871), 18 Gr 572 (Ont Ct Ch).

Chambers, "Resulting Trusts," supra note 4 at 391.

For the negative intent framework, see Air Jamaica Ltd v Charlton, [1999] UKPC 20, [1999] 1 WLR 1399; Twinsectra Ltd v Yardley, [2002] UKHL 12, [2002] 2 AC 164. For the positive, see Westdeutsche, supra note 26.

31 See e.g. Calverley v Green, [1984] HCA 81, 155 CLR 242 [Calverley]; Dullow v Dullow, [1985] 3 NSWLR 531 at 535 [Dullow]; Lau Siew Kim v Yeo Guan Chye Terence, [2007] SGCA 54, [2008] 2 SLR (R) $108[\mathrm{Lau}]$. In addition, English and American courts have refused to apply the presumption of resulting trust in respect to interests in land: see Restatement (Third) of Trusts: Purchase - Money Resulting Trusts $\$ 9$ (2003); Lohia v Lohia (2000), [2001] WTLR 101 (HC (QBD)). On this point, "no concluded view" was given by the Court of Appeal, see [2001] EWCA Civ 1691 at para 26. 
intended to set up a trust because that would be a very confusing question to ask. Put differently, we find that the negative intent framework is simply a more intuitive way of thinking about the intentions of lay RRSP and RRIF investors. Indeed, even strong supporters of the positive intent framework do not "seek to defend the continuation in the modern day of a presumption of declaration of trust where the common experience is that citizens do not generally create trusts for themselves." 32

\section{B. Holders OF THE EVIDENCE AND MANAGERS OF ASSETS}

At times, courts have upheld or narrowed the presumptions, not by reference to intent, but for their practical benefits. In particular, courts have suggested that presumed resulting trusts are advantageous because they place the burden to supply evidence on those more likely to have the evidence - the transferees. Another potential practical benefit posited by courts relates to the management of assets. In fact, the presumption of advancement was narrowed in Pecore, in part to make it easier for adult children to manage their parents' affairs. ${ }^{33} \mathrm{As}$ with intent, we will later suggest that these practical benefits are inapplicable in the context of beneficiary designations.

\section{HOLDERS OF THE EVIDENCE}

As noted above, the presumption of resulting trust was useful in 15th century England because it placed the burden of evidence on those more likely to possess that evidence. The majority in Pecore relied on the same justification. They stated that in situations in which the transferor is deceased and the dispute is between the transferee and a third party, the presumption of resulting trust places the burden of proof on the party that is "better placed to bring evidence about the circumstances of the transfer." 34 For example, imagine a typical resulting trust scenario where the deceased made a gratuitous transfer to a party. That transferee then gets involved in a dispute with the deceased's estate over the transfer. As the estate is often not involved in the transfer (and is surprised to find out about it), it is sensible to put the burden of proof on the recipient, who is more likely to have some documentation or other evidence regarding the putative gift.

\section{MANAGERS OF ASSETS}

The Supreme Court of Canada in Pecore justified the abolition of the presumption of advancement between parents and adult children as a way to "facilitate the free and efficient management of that parent's affairs." 35 Pecore came about in the context of a father and daughter sharing a joint bank account, and the Court was concerned such an arrangement would be mistaken for a gift. In other words, the Court refrained from interfering with an increasingly common financial management scheme. While this justification logically applies to joint management of a bank account, it is unclear how it would apply to designated beneficiaries who do not play a financial management role or have any access to the registered account.

Swadling, supra note 6 at 84 [emphasis added].

Pecore, supra note 2 at para 36.

Ibid at para 26.

Ibid at para 34, citing McLear v McLear Estate (2000), 33 ETR (2d) 272 at para 41 (Ont Sup Ct J). 


\section{Transactional Certainty}

Courts have also stressed the role the presumptions play in transactional certainty. For example, in Plamondon v. Czaban, ${ }^{36}$ the Alberta Court of Appeal upheld the presumption of advancement because of the certainty it yielded in gift-giving. The Court stated that to abolish the presumption of advancement and thus subject all gratuitous transfers to resulting trusts "would upset a vast number of gifts every day. No expensive Christmas or birthday present would be safe." ${ }^{, 37}$ Australian courts have espoused a similar view. ${ }^{38}$

Further, Justice Feldman's dissent in the Ontario Court of Appeal's decision in Saylor v Madsen Estate discussed the continuing relevance of the presumptions in terms of transactional certainty. ${ }^{39}$ She suggested that while the presumptions may be anachronistic, they do provide certainty and predictability by guiding judicial determination of beneficial ownership. ${ }^{40}$ In other words, abolishing the presumptions would give way to uncertainty because every case would require a full examination of the circumstances of the transfer. This task is especially difficult when the transferor is deceased, as is common in litigated disputes. Justice Feldman suggested that if the presumption of resulting trust was abolished, transactional certainty could be retained by giving the designating document prima facie evidence of intent. ${ }^{41}$

\section{The Application of the Presumption of RESUlting TRUST TO BENEFICIARY DESIGNATIONS}

Based on the law reviewed above, it is unclear that the presumption of resulting trust should apply to designated beneficiaries. On one hand, no consideration passes and thus beneficiary designations are gratuitous transfers in the spirit of joint bank accounts in Pecore. On the other hand, the designation of a beneficiary, prima facie, suggests that the transferor considered whether a beneficial interest should pass, and indeed intends to pass the interest to the designated party. In this vein it seems logical that either the presumption of resulting trust would be rebutted by the designation itself, or that it never arises because the transferor did intend to pass a beneficial interest (under the negative intent framework), or did not intend to set up a trust (under the positive intent framework). Indeed, why bother designating anyone if the presumption is that the investment will pass to the owner's estate?

Surprisingly, England, Manitoba, British Columbia, and Ontario do apply the presumption of resulting trust to beneficiary designations. Only one province - Saskatchewan — takes the position that the presumption of resulting trust does not apply to beneficiary designations. We review both legal positions, beginning with Saskatchewan's. 


\section{A. Saskatchewan: The Presumption of Resulting Trust DOES Not APPLY TO BENEFICIARY DESIGNATIONS}

The position in Saskatchewan, arising from Nelson et al. v. Little Estate, is that the presumption of resulting trust does not apply to beneficiary designations. ${ }^{42}$ In Nelson, Mildred Little transferred a bank account into the joint names of herself and her son, James. She also designated James as her beneficiary under a RRIF. The evidence, unchallenged by James, suggested that Mildred did not intend a gift to James, but rather that both her bank account and RRIF were to benefit her grandchildren. ${ }^{43}$

The Saskatchewan Court of Appeal drew a distinction between the joint bank account and the RRIF. The presumption of resulting trust applied to the funds in the joint bank account and thus these funds resulted back to Mildred's estate. The RRIF was a different story. The Court expressly held that the presumption of resulting trust does not apply to RRIFs (but did so without explanation). Ultimately however, the RRIF passed to Mildred's estate due to her stated intention. ${ }^{44}$ England, Manitoba, British Columbia, and Ontario have taken a different and more problematic stance.

\section{B. The Presumption of Resulting Trust APPLIES TO BENEFICIARY DESIGNATIONS}

In England, the presumption of resulting trust applies to beneficiary designations. In Re A Policy No. 6402 of the Scottish Equitable Life Assurance Society, a decision of the Chancery Division, influenced a great deal of the subsequent case law in both England and Canada. ${ }^{45}$ The case involved a curious set of facts. William Sanderson took an insurance policy out on his life, with Harriott Stiles as the designated beneficiary. William's wife died a few months later, and two years after that, he married Harriott, who was in fact his deceased wife's sister. The issue to be determined was whether the estate or Harriott was entitled to the funds of the insurance policy after William's death. ${ }^{46}$

The Court surveyed cases of purchase money resulting trusts and found that the designation of a life insurance beneficiary was no different - something was bought in the name of another with no consideration changing hands. ${ }^{47}$ With no evidence of William's intention beyond the insurance policy itself, the Court held that the insurance proceeds should result back to his estate. ${ }^{48}$ Re Scottish Equitable played a significant role in the development of the case law in Manitoba, which agrees that the presumption of resulting trust applies to beneficiary designations.

In the Manitoba Court of Appeal's decision in Dreger (Litigation Guardian of) v. Dreger, the decedent Helena Dreger left behind two adult children (Dwayne and Stephanie) and an

2005 SKCA 120, [2006] 8 WWR 236 [Nelson].

Ibid at paras $2-3$.

Ibid at paras 18-19.

(1901), [1902] 1 Ch 282 [Re Scottish Equitable].

Ibid at 283 .

Ibid at 286 .

Ibid at 287. 
infant daughter (Morgan). ${ }^{49}$ A large portion of Helena's holdings were in the form of life insurance policies and an RRSP. There was some evidence Helena had told her lawyer that she wished the insurance proceeds and RRSP funds to form part of her estate. She also made it clear that $\$ 5,000$ per year should go from her estate to whomever was looking after Morgan. Unfortunately for Helena, Dwayne was the named beneficiary for both the life insurance policies and the RRSPs, and thus those funds never reached the estate. Worse still, without those funds, the estate quickly ran dry, and with it Morgan's maintenance payments. An action was brought in Morgan's name against Dwayne..$^{50}$

Morgan's first argument was that Dwayne held the funds as trustee of an express trust for the benefit of the estate. The Appellate Court was hamstrung in making this finding, however, as the trial judge had found that the decedent never communicated any intent to her son that he should act as trustee for the funds in question. ${ }^{51}$ The Court refrained from following a line of United States cases holding that a valid express trust of a life insurance policy could be created when the named beneficiary had no prior knowledge he was to hold the funds in trust for others. ${ }^{52}$ US case law is also divided on this issue, but for very different reasons than Canadian courts.

In the US, the law surrounding resulting trusts is vastly different from that in Canada a resulting trust does not automatically arise from a gratuitous transfer of property. Instead, where it appears that the transferor did not intend to make a gift, but instead to retain the beneficial interest in the property, a court can find that an express trust arises through the words or conduct of the transferor. ${ }^{53}$ Therefore, in a challenge to a beneficiary designation, US courts consider whether an express trust has been created by the transferor. In doing so, the court will determine if the transferor intended for the designated beneficiary to hold the proceeds in trust for a third party. Intent is typically found by evidence showing that the trustee communicated to the beneficiary that he or she was to hold the proceeds in trust. ${ }^{54} \mathrm{In}$ some cases, courts have found a trust where there has not been such communication, although there are conflicting decisions on this point. Still, all US courts start from a presumption of a gift in the proceeds, rather than a presumption of resulting trust.

The Manitoba Court of Appeal refrained from importing the US position. Instead, the Court followed Re Scottish Equitable, and found that designated beneficiaries in registered accounts and insurance contracts were subject to the presumptions of resulting trust and advancement. ${ }^{55}$ As this was a pre-Pecore decision, the presumption of advancement applied to this transfer from a mother to an adult son, but this presumption was extremely weak, "held from falling by nothing more than a spider's thread."

The Court then went to great lengths to ascertain evidence of intention that would defeat that thread. The problem was that Helena was not aware of her medical condition when most

[1994] 10 WWR 293 [Dreger].

Ibid at paras 2, 6, 11, 13.

Ibid at para 14.

Ibid at paras $17-22$.

Austin Wakeman Scott, William Franklin Fratcher \& Mark L Ascher, Scott and Ascher on Trusts, 5th ed (New York: Wolters Kluwer Law \& Business, 2006) vol 6 at $§ 40.2$.

Ibid, vol 1 at $\$ 8.2 .3$.

Dreger, supra note 49 at para 27.

Ibid at para 31 . 
of the designations were made, resulting in a lack of contemporaneous evidence of intention that the proceeds should ultimately wind up with her estate. However, she did make one designation after her cancer diagnosis, and at approximately the same time she instructed her lawyer that the proceeds of the RRSP and life insurance contracts should benefit her estate and thus her young daughter. The Court decided that "[o]nce it is established that one of the four contracts was intended as an estate asset, it is reasonable to draw the inference of a similar intention with respect to the earlier contracts." 57

The British Columbia Superior Court expressly followed Dreger in Neufeld v. Neufeld Estate, ${ }^{58}$ holding that the presumption of resulting trust applies to the designation of a beneficiary for the proceeds of a RRIF. There are currently no British Columbia appellate court decisions on the issue.

The Ontario Superior Court of Justice's decision in McConomy-Wood v. McConomy ${ }^{59}$ concerned a dispute between siblings for their parents' RRIF, valued at nearly $\$ 400,000$. The elder McConomys - Lillian and Douglas — were both stricken with cancer and died within months of each other. Lillian outlived Douglas, and about a month before dying she designated their daughter Lisa as beneficiary. Lillian's will did not mention the RRIF. A dispute arose between Lisa and her brothers over the proceeds of the RRIF. ${ }^{60}$

Justice Herold, despite noting that Pecore and Madsen were in the context of joint bank and investment accounts, applied their reasoning regarding the presumptions of resulting trust and advancement. ${ }^{61}$ There was ample evidence that Lillian, during her final days, wished for her three children to be treated equally. Justice Herold therefore found that there was no need to rely on the presumptions - Lisa held the RRIF proceeds in trust for the estate. $^{62}$ Justice Herold noted that if a presumption did apply, he would follow Pecore and refrain from applying the presumption of advancement in the case of an adult child (that is, Lisa). ${ }^{63}$

In summary, Canada has seen conflicting decisions at the appellate level. In Saskatchewan the presumptions do not apply to beneficiary designations, while in Manitoba they do. Ontario and British Columbia's trial level decisions suggest that courts in those provinces will apply the presumptions to beneficiary designations. These cases set the stage for Alberta's first chance to consider the issue, which also represents only the second postPecore case on this point.

Ibid at para 39.

2004 BCSC 25, 5 ETR (3d) 188.

(2009), 46 ETR (3d) 259 [McConomy-Wood].

Ibid at paras 2, 7, 45 .

Ibid at para 53 .

Ibid at para 58 .

Ibid. 


\section{MORRISON ESTATE (RE)}

\section{A. The FACTS}

John Morrison left his estate to be divided equally among his four children. Just prior to his death, John sold his house and split the proceeds equally among the four. John's most valuable asset, however, was a RRIF, and he only designated his son Douglas as a designated beneficiary. Douglas received the proceeds of the RRIF, but the tax burden fell on the estate. With the combination of losing the proceeds of the RRIF and paying out the taxes on the RRIF, there were not enough assets left in the estate to satisfy the specific cash bequests to John's grandchildren. ${ }^{64}$

Douglas' siblings were unhappy about this situation, and brought an application for a declaration that Douglas held the RRIF proceeds in trust for the estate. They argued that Douglas gave no consideration for the RRIF and thus, pursuant to Pecore, the proceeds should result back to the estate. ${ }^{65}$

\section{B. Should the Presumption of Resulting Trust APPLY TO BENEFICIARY DESIGNATIONS?}

The primary issue facing the Court was whether the presumption of resulting trust applies to beneficiary designations as gratuitous transfers. Or, is there something special about beneficiary designations that take them outside the realm of the presumptions? Justice Graesser noted that "[i]t is frequently said that hard cases make bad law, and there is certainly the potential for a hard case such as this to impact many other plan or policy owners and their designated beneficiaries." 66

Indeed, if the presumption of resulting trust applies to beneficiary designations, then absent relationships triggering the presumption of advancement, courts must presume that the proceeds of RRSPs and RRIFs result to the estate. Pecore rendered this issue even more serious by abolishing the presumption of advancement between parents and adult children. In other words, if Pecore had retained the presumption of advancement between parents and adult children, then adult children could rely on that presumption when designated as a beneficiary. A holding applying the presumption of resulting trust in Alberta would place designated beneficiaries on shakier ground - they would be forced to adduce evidence that their parent intended them to benefit. And given the counterintuitiveness of the rule, who would think to retain such evidence? For instance, children named as beneficiaries in their parents' wills are not, as a matter of course, asked to provide evidence of their parents' intent that that gift should pass to them. We expect few would think to secure such evidence. We further explore this analogy between beneficiary designations and testamentary dispositions when we discuss options for judicial reform.

Justice Graesser equivocated on whether the presumptions apply to beneficiary designations. Despite his misgivings regarding the potential effects on millions of 
beneficiaries, he stated he was bound by the weight of previous Canadian decisions that applied the presumptions. ${ }^{67}$ Still, there was some evidence of intention, and thus Justice Graesser was able to avoid reliance on any presumption. ${ }^{68}$ Interestingly, however, he tacitly accepted the presumption of resulting trust by shifting the onus to Douglas (the respondent in the action) to demonstrate that his father intended him to retain the proceeds of the RRIF. ${ }^{69}$ Morrison raises questions about the nature of resulting trusts, the rationale for imposing them, and whether these rationales apply to beneficiary designations.

\section{Justice Graesser's Reasons}

Justice Graesser reviewed the case law outlined above, and eventually accepted the precedents set down in Re Scottish Equitable, Dreger, and McConomy-Wood, while still expressing concern about their implications on transactional certainty. In particular, he worried their dicta would "create untold uncertainties in what are likely hundreds of thousands if not millions of beneficiary designations in Canada." ${ }^{, 70}$ In other words, the Court in Pecore did not seem to foresee that its holding would put millions of designated beneficiaries at risk. ${ }^{71}$

Justice Graesser also noted that the presumptions should not apply to RRSP and RRIF beneficiary designations because they bear similarities to beneficiary designations under a will. Testamentary gifts cannot be challenged by the presumption of resulting trust because it is presumed that the donor intended to give a gift. Beneficiary designations and testamentary gifts share many similarities: they do not take effect until the death of the owner of the plan; they can be changed by the donor during his or her life; and, they do not confer a present proprietary interest in the beneficiary. ${ }^{72}$ There are therefore many reasons to treat beneficiary designations and testamentary gifts similarly.

Despite the above points, and although he was "sorely tempted" to hold that beneficiary designations "should be treated differently from other forms of gifts," Justice Graesser ultimately accepted the position flowing from Re Scottish Equitable. ${ }^{73}$ Put slightly differently, the weight of precedent carried the day: "I am mindful of stare decisis and am loathe on the facts of this case to reject what appears to be settled law in England through [Re Scottish Equitable] and the Manitoba Court of Appeal in [Dreger]."

Still, Justice Graesser did not need to apply the presumptions because he was able to find evidence of intention. He did, however, seem to tacitly apply the presumption of resulting trust. He framed the legal issue as "has Douglas proven on a balance of probabilities that his father intended to give Douglas the RRIF?"75 By placing the onus of proof on Douglas (the respondent), the recipient of the RRIF proceeds, Justice Graesser applied the presumption 
of resulting trust de facto; he shifted the burden of proof to the gratuitous donee to prove that a gift was intended.

Justice Graesser ultimately relied on ambiguous evidence to find that John intended a gift. He stated "that this [was] a very thin finding" with "slightly more evidence of an intention to favour Douglas than to have Douglas hold the RRIF as a resulting trust for the estate or his siblings." ${ }^{76}$ Justice Graesser relied upon:

(1) The close relationship between Douglas and his father ... at the time of the beneficiary designation;

(2) The assistance rendered to Mr. Morrison by Douglas in the time surrounding and immediately following Mrs. Morrison's death; and

(3) The close temporal connection between the making of the will appointing Douglas and Heather joint alternate executors and the signing of the beneficiary designation in favour of Douglas only. ${ }^{77}$

This third point — that only Douglas was designated as beneficiary — illustrates why the application of the presumption of resulting trust in beneficiary designations is problematic. As Justice Graesser noted, there is no need to designate a beneficiary in a RRIF. ${ }^{78}$ Where there is no designated beneficiary, the policy simply transfers to the estate on the death of the policyholder. Therefore, if John had really wanted to leave the RRIF to his children in equal shares, he could have refused to make a designation. Instead, John made a positive choice to change this default position.

Additionally, Justice Graesser imposed a constructive trust over the proceeds of the RRIF in favour of the estate in the amount of the tax paid by the estate on the RRIF. He found jurisdiction under Alberta's Judicature $A c t^{79}$ to fashion an equitable remedy for the unfairness of having the estate pay the tax on the RRIF. ${ }^{80}$ Justice Graesser imposed the constructive trust as an equitable remedy on the grounds that either Douglas was unjustly enriched by the estate giving him the benefit of paying the tax on his behalf, or that the tax paid by the estate resulted from John's mistaken belief in the consequences of designating a beneficiary. ${ }^{81}$

As reviewed above, Justice Graesser was live to the dangers of applying the presumption of resulting trusts to beneficiary designations. In the face of Canadian and foreign precedent, he did not undertake a thorough analysis of these dangers. Further, he did not consider the theoretical and practical considerations underpinning the presumptions. We perform this analysis in the following section, finding scant reason to apply the presumption of resulting trust to beneficiary designations. 


\section{The Presumption of Resulting Trust SHOUld Not APPly TO DESIGNATED BENEFICIARIES}

As reviewed above, courts have found that the equitable presumptions serve many salutary purposes. They operate to fulfill the intentions of the transferor. They may also harmonize the law with efficient financial planning and put the burden of evidence on the party with greater access to the evidence. Finally, the presumptions can promote transactional certainty. In the following section we demonstrate that none of these rationales apply to beneficiary designations.

\section{A. The INTENTION OF THE Transferor}

Scholars find that gratuitous transfer resulting trusts are premised either on a lack of intent to pass a beneficial interest, or a positive intent to set up a trust in the transferor's favour. On either basis, there is no logic in applying a resulting trust to gratuitous beneficiary designations. The act of designating a beneficiary, on its face, establishes intent to transfer a beneficial interest and is inconsistent with establishing a trust in one's own favour. In this respect beneficiary designations are clearly distinguishable from the more common fact pattern in which a party gratuitously contributes to the purchase price of real or personal property, of which legal title is held by another (that is, the purchase money resulting trust). ${ }^{82}$ In such cases there is often no evidence of intent to pass a beneficial interest, and thus there is reason to subject the transaction to the presumption of resulting trust. The same cannot be said for beneficiary designations.

\section{B. AN EMPIRICAL EXAMINATION OF DONATIVE INTENT IN BENEFICIARY DESIGNATIONS}

Rather than relying solely on our assumptions regarding what investors intend when designating beneficiaries, we decided to obtain a more objective assessment. We conducted an empirical study of what investors intend when designating beneficiaries for an RRSP. The study's results strongly suggest that when investors designate their adult son or daughter as a beneficiary, they intend that person, and not the estate, to receive the proceeds of the RRSP on their death.

\section{MATERIALS AND METHODOLOGY}

We asked participants to imagine they were opening an RRSP and had chosen to designate their adult son or daughter as the beneficiary. Then we asked if that designation reflected an intent that the proceeds of the RRSP should go to their estate, or to the son or daughter they designated. Participants then reported their understanding of the terms "estate" and "RRSP," as a check to ensure they understood these concepts. We also asked participants their age and about their level of financial knowledge because of the possibility these variables might predict whether participants knew about the law surrounding beneficiary designations (see Appendix A). 
Recent research demonstrates that scientists' failure to employ best practices has seriously biased the publicly available science and presents drastic consequences for law. ${ }^{83}$ To combat this trend, researchers suggest adopting an open and preregistered design (that is, publicly commit to a set of procedures that are open to scrutiny). ${ }^{84}$ We adopted this practice, posting our study's materials and protocols online prior to collecting data. ${ }^{85} \mathrm{We}$ initially planned to recruit 100 participants from Amazon's Mechanical Turk (MTurk ${ }^{86}$ platform, which provides a demonstrably reliable source of data. ${ }^{87} \mathrm{We}$ did not foresee, however, that few Canadians use MTurk and we were only able to collect samples from 14 individuals. As a result, we recruited an additional 46 participants from the support staff at a large Toronto law firm.

\section{RESULTS AND CONCLUSION}

Participants overwhelmingly indicated that RRSP beneficiary designation constitutes intent that the money from their RRSP should go to the named beneficiary, rather than to the estate. In fact, all but two indicated this was the case ( 97 percent of the sample). Given the lack of variation in the intent measure, there is no utility in correlating it with the measures of financial fluency. However, it is worth noting that self-reported financial knowledge was between little (coded as 2) and some (3) investment knowledge (Mean = 2.40; Standard Deviation $=.82) .{ }^{88}$ The average age was $37.96($ Standard Deviation $=12.97)$.

The results of this modest study suggest individuals, when designating their adult child as beneficiary to an RRSP, intend that adult child to ultimately receive the proceeds of the RRSP. In this respect, the study supports our intuitions regarding intent in beneficiary designations. It also supports what we expect is common sense among most Canadians: a beneficiary designation, on its face, confers a beneficial interest.

Researchers may wish to follow up on this study by broadening its scope. Participants in the present study reported a low to moderate level of investment knowledge. Most were also employed at a law firm as administrative assistants, marketers, and various other support staff. However, if anything, one would expect employees at a law firm to have a more sophisticated understanding of the law than the general population. There is therefore no reason to think the general population would be more likely to hold different intentions.

Taken as a whole, the law flowing from Pecore and Morrison thwarts the intentions of those making beneficiary designations. Unlike joint bank accounts (and other forms of

Jason M Chin, "Psychological Science's Replicability Crisis and What It Means for Science in the Courtroom" (2014) 20:3 Psychol Pub Pol'y \& L 225.

Eric Eich, "Business Not as Usual" (2014) 25:1 Psychological Science 3.

All materials, data, and preregistration information available online: Jason M Chin, Archie Rabinowitz \& Aoife Quinn, "Intent for Resulting Trusts in RRSP Beneficiary Designations" (5 May 2016), Open Science Framework, online: $<$ https://osf.io/4pw9z/>.

Amazon Mechanical Turk, online: <www.mturk.com>.

Michael Buhrmester, Tracy Kwang \& Samuel D Gosling, “Amazon’s Mechanical Turk: A New Source of Inexpensive, Yet High-Quality, Data?” (2011) 6:1 Perspectives on Psychological Science 3.

Financial knowledge was coded as follows: 1 - no knowledge; 2 - little knowledge; 3 - some knowledge; 4 - a lot of knowledge; 5 - expert. Further, only six participants evidenced no knowledge of what an RRSP was by either not defining it or providing an incorrect definition (for example, "savings account for guaranteed monthly income"). Seventy-five percent of participants correctly defined estate. The latter two findings were provided by a blind coder asked to determine if the definitions provided were reasonably accurate. 
property for that matter), adults do not designate beneficiaries to manage their funds while simultaneously retaining a beneficial interest — that's simply not how such designations work. Instead, beneficiaries are designated to take ownership of the assets on the death of the registered account holder. To apply the presumption of resulting trust to such designations ignores and often contradicts the intent of the designating party. This betrayal of intent is antithetical to any conception of the law of resulting trusts.

\section{Practical Benefit}

The Supreme Court of Canada in Pecore posited an additional role for the presumption of resulting trust: it should "facilitate the free and efficient management of that parent's affairs." ${ }^{89}$ Once again, while a rebuttable presumption that the adult child is holding the property in resulting trust for the parent may be useful for financial management, the same logic simply does not hold for beneficiary designations. Rather, designated beneficiaries play a passive and delayed role in elders' financial planning. This is because, unlike the bulk of the gratuitous transfer case law (of which Morrison and its ilk drew from), a beneficiary designation does not confer a present legal interest. The presumption of resulting trust therefore lends no practical benefit to financial management.

The Supreme Court of Canada in Pecore also suggested that the application of the presumption of resulting trust carried the advantage of placing the burden of evidence on the party more likely to possess the evidence..$^{90}$ This represents a benefit in cases like Pecore, where a joint account holder was likely present during the opening of the account and involved with his or her parent's financial affairs. In such cases, the child is probably better placed than the estate to adduce evidence. However, the same is not true for designated beneficiaries who do not need to be involved or even consulted when they are designated. Indeed, in Dreger, the designated beneficiary was not aware he had been designated. ${ }^{11}$ When disputes do arise between the designated beneficiary and the estate, it is likely that the estate trustee will have greater access to the deceased's documents. The designated beneficiary, if anything, has less of an evidential advantage and thus the evidence rationale does not apply.

\section{Transactional Certainty}

An additional argument for retaining the presumptions is that they promote certainty and predictability. In particular, Justice Feldman in Madsen Estate worried that without the presumptions, transfers would be subjected to unstructured judicial inquiries before transferees could confidently retain their assets. She suggested an increased number of cases would be decided by "the vicissitudes of the anecdotal evidence that may be brought forward." 92 While this may be the case with gratuitous transfers of personal property, it does not apply to beneficiary designations. They, in all cases, are documented by the account holder's written designation establishing intent to pass a beneficial interest. 
More uncertainty results from retaining the presumption of resulting trust in beneficiary designations. Indeed, Justice Graesser noted in Morrison that the application of resulting trust to beneficiary designations would create "untold uncertainties" $" 93$ in potentially millions of investments. He is likely referring to the fact that because most people assume and intend that these designations will be effective, to hold otherwise creates uncertainty.

\section{E. RE SCOTTISH EQUitable IS PER INCURIAM}

Finally, Canada's position on the application of the presumption of resulting trust traces back to dubious authority. This case, Re Scottish Equitable, was deemed "definitive" as to whether the presumption of resulting trust applies to beneficiary designations in Manitoba. ${ }^{94}$ It was also persuasive in Morrison. ${ }^{95}$ As shall be seen, however, Re Scottish Equitable (1) did not rely on any relevant authority for its main proposition, (2) has been roundly criticized in its own jurisdiction, and (3) is inapplicable to the facts in Morrison.

First, Re Scottish Equitable did not actually rely on any authority for the principle it is cited for in Canada. As reviewed above, Re Scottish Equitable has been cited for the holding that the presumption of resulting trust extends beyond gratuitous transfers of real and personal property to beneficiary designations. Re Scottish Equitable did not actually rely on any cases that made such a leap. Instead, the Chancery Division rested its decision primarily on Dyer $v$. Dyer ${ }^{96}$ a purchase money resulting trust case (that is, a resulting trust that arises when a person purchases land in the name of another). In that case, Mr. Dyer provided the purchase money for land held jointly by his family. The Court in Dyer held that the presumption of resulting trust applied in such circumstances. ${ }^{97}$

Re Scottish Equitable relied on three other decisions, which were also not beneficiary designation cases, but rather gratuitous transfer or purchase money cases involving bonds and annuities. Ebrand v. Dancer ${ }^{98}$ concerned a bond purchased by a grandfather in the name of his grandchild. Rider $v$. Kidder ${ }^{99}$ was a case of a man purchasing an annuity in the name of himself and a woman with whom he was cohabitating. Finally, in Garrick v. Taylor, ${ }^{100}$ a woman bought shares in a joint stock bank and transferred them into the name of an older woman with whom she cohabitated. Re Scottish Equitable offered no analysis regarding why it was appropriate to apply the presumption of resulting trust to designated beneficiaries, nor did it consider the policy implications of doing so. And, of course, the Court could not have foreseen the consequences to millions of designated beneficiaries under RRSPs and RRIFs across the Atlantic Ocean.

Re Scottish Equitable also failed to follow controlling authority, a point for which it was subsequently criticized. In particular, it failed to follow a Court of Appeal decision: Cleaver v. Mutual Reserve Fund Life Association. ${ }^{101}$ In that case, the deceased's executors objected

Morrison, supra note 1 at para 53.

Dreger, supra note 49 at para 25.

Morrison, supra note 1 at para 64.

(1788), 30 ER 42 (Ex Ct) [Dyer].

Ibid at 45 .

(1680), 22 ER $829(\mathrm{Ch})$.

(1805), 32 ER 844 (Ch).

(1860), 54 ER 556 (Rolls Ct), aff'd (1861) 45 ER 1144 (Ch).

Cleaver v Mutual Reserve Fund Life Association (1891), [1892] 1 QB 147 (CA) [Cleaver]. 
to a widow collecting a life insurance policy that the deceased had purchased in her name, because she murdered the deceased. While Cleaver is best known for its holding on the rule of forfeiture, it also contains an important discussion on the approach to the ownership of life insurance policies, and was followed on that point in subsequent cases of the Chancery Court. ${ }^{102}$ The Court of Appeal in Cleaver viewed the issue of designated beneficiaries in life insurance policies as governed by contract law. Absent a statutory regime, the wife (beneficiary) had no interest in the policy and therefore no standing to sue upon it. In other words, the life insurance policy was a contract between the deceased and the insurance company, and the beneficiary had no privity to sue on it. ${ }^{103}$

Later cases treated Re Scottish Equitable disapprovingly, noting that it failed to rely on controlling authority. For instance, in Re Engelbach's Estate, the Chancery Court declined to follow Re Scottish Equitable. In Re Engelbach's Estate, the issue before the Court was whether the deceased's daughter or the estate was the owner of the life insurance policy. The Court declined to afford Re Scottish Equitable any weight because it did not cite Cleaver, and it did not consider the point that the wife had never obtained a legal interest in the insurance monies. $^{104}$

Finally, Re Scottish Equitable is likely inapplicable in Alberta due to Alberta's statutory insurance regime. Alberta's Insurance Act provides that upon designation of a beneficiary, insurance money never reaches the estate, going directly to the beneficiary:

Insurance money not part of estate

666(1) If a beneficiary is designated, any insurance money payable to the beneficiary is not, from the time of the happening of the event on which the insurance money becomes payable, part of the estate of the insured and is not subject to the claims of the creditors of the insured. ${ }^{105}$

Therefore, in the face of Alberta's insurance regime, the beneficiary in Re Scottish Equitable (the sister of the insured's wife) would have likely prevailed and the funds would not have resulted back to the estate. Simply put, Re Scottish Equitable's holding — that the presumption of resulting trust applies to designated beneficiaries in insurance schemes should not have been relied on in Morrison.

\section{SOLUTIONS}

Having concluded that the traditional rationales for employing the presumption of resulting trust do not apply to beneficiary designations, and that legal precedent for using the presumption this way is sparse, what can be done? Below, we provide judicial and legislative solutions, as well as solutions that can be implemented by banks.

RSA 2000, c I-3, s 666(1). Other provinces have similar regimes, see e.g. Insurance Act, RSBC 2012, c 1, s 65(1); The Saskatchewan Insurance Act, RSS 1978, c S-26, s 158(1); Insurance Act, RSO 1990, c I.8, s 196(1). 


\section{A. JUdicial REForM}

The simplest answer is to give effect to Justice Feldman's suggestion in Madsen Estate, where she said that if the presumptions are abolished, bank documents indicating a right of survivorship should serve as prima facie evidence of a gift. ${ }^{106}$ Justice Abella made the same point in her concurrence in Pecore. She suggested that bank accounts confirming a survivorship interest "should be deemed to reflect an intention that what has been signed, is sincerely meant." ${ }^{107}$ She disagreed with Justice Rothstein on this point, who held that banking documents are at most "strong evidence" 108 of the intent to pass a beneficial interest. In the context of designated beneficiaries, which did not appear to be contemplated by the majority in Pecore, Justice Abella's approach is more compelling. One has difficulty conceiving of situations in which account holders would not think that designating a beneficiary confers a beneficial interest. Indeed, the empirical evidence presented above confirms this suspicion. Giving prima facie effect to beneficiary designation documents carries many advantages. As mentioned, it respects the intention of the transferor. It also serves as transactional certainty. Courts have expressed concern that limiting or abolishing the resulting trust would increase the risk of litigation and thus create uncertainty over whether parties can rely on a completed transaction. Giving prima facie effect to bank documents would avoid disputes in the same manner as a presumption. It may even promote certainty as any dispute would largely be governed by reliable documentary evidence, rather than the more indeterminate inquiry prescribed in Pecore. ${ }^{109}$

The Supreme Court of Canada in Pecore laid out several forms of evidence that courts can consider to determine the intent of transferors in joint bank account cases. Most of this evidence is far less reliable than a written designation in a bank document. This included evidence such as actions subsequent to the transfer, and control and use of the funds in a joint bank account. ${ }^{110}$ When there is documentary evidence of a beneficiary designation, it is hard to imagine cases when evidence subsequent to the transfer would be more probative than documentary evidence contemporaneous to the designation. The beneficiary designation cases reviewed herein support this notion, as courts appear to regularly indulge in protracted inquiries into the transferor's intent, following thin findings and spider threads.

Moreover, an analogy may be drawn to the evidence regularly relied on in cases of contractual interpretation where, as here, the court's task is to determine the intentions of the parties when the agreement was made. ${ }^{111}$ In this determination, the words of the contract are at the centre of the inquiry. ${ }^{112}$ Subsequent conduct evidence is admissible as an interpretive aid, but it is given less weight and is only admissible if the contract is ambiguous on its face. ${ }^{113}$ For example, the British Columbia Court of Appeal issued a caution against affording too much weight to subsequent conduct: "In no case is it necessary that weight be given to

Madsen Estate, supra note 39 at para 81.

Pecore, supra note 2 at para 104.

Ibid at para 61 .

Ibid at paras 55-70.

Ibid at paras 56-59, 62-66.

Geoff R Hall, Canadian Contractual Interpretation Law, 2nd ed (Markham: LexisNexis, 2012) at 9; Consolidated-Bathurst Export Limited v Mutual Boiler \& Machinery Insurance Co (1979), [1980] 1 SCR 888 at 899.

Eli Lilly \& Co v Novopharm Ltd, [1998] 2 SCR 129 at para 54.

Hall, supra note 111 at 82 . 
evidence of subsequent conduct. In some cases it may be most misleading to do so and it is to this danger that allusions are made throughout the recent English cases."114 This position from the well-developed law of contractual interpretation should guide the interpretation of beneficiary designations. In other words, primacy should be given to the words of the designation.

Rather than the above steps, courts may consider retaining the presumption of advancement for beneficiary designations, regardless of the age of the child. As reviewed above, there are two rationales for the presumption of advancement to children: a moral obligation to support their children, and parental affection. Both of these rationales readily apply to beneficiary designations.

It seems reasonable to assume that many parents designate their children, adult or otherwise, as beneficiaries on their registered accounts out of a moral obligation to support their children once they have passed away. While empirical evidence would be useful in confirming this suggestion, there appears to be a clear distinction between joint bank accounts and beneficiary designations in this regard. The rationale for financial management identified by the Supreme Court in Pecore is not applicable, and there is no fear that the transferor's assets need to be protected. Moreover, and echoing Justice Abella in Pecore,${ }^{115}$ there is no good reason to ignore the motivation of parental affection. One would expect that many, if not most, designations of children as beneficiaries are driven by the intent to benefit that child due to love and affection.

Finally, courts may wish to define beneficiary designations as testamentary dispositions, thus removing them from the resulting trust regime and placing them in the wills framework. ${ }^{116}$ Recall that in Morrison, this is precisely what Justice Graesser considered, but ultimately refrained from doing. ${ }^{117}$ As we discuss below, beneficiary designations have much more in common with testamentary dispositions than inter vivos gifts, and in fact likely meet the common law tests for testamentary dispositions. Still, courts should exercise caution in deeming beneficiary designations as testamentary because provincial statutes contain varying levels of formal requirements for testamentary dispositions. If banks are not aware of the requirements, the effectiveness of beneficiary designations could be put at risk.

The common law has established multiple tests to determine whether a disposition is testamentary. A particularly well-trod ${ }^{118}$ version traces to Cock v. Cooke, ${ }^{119}$ and focuses on whether the disposition relies on the death of the transferor: "It is undoubted law that whatever may be the form of a duly executed instrument, if the person executing it intends that it shall not take effect until after his death, and it is dependent upon his death for its vigour and effect, it is testamentary." ${ }^{20}$ Similarly, in Elliott v. Turner, the Ontario High Court of Justice enunciated four factors suggestive of a testamentary disposition: " 1 . No

Re Canadian National Railways and Canadian Pacific Ltd (1978), 95 DLR (3d) 242 (BCCA) at 262. Pecore, supra note 2 at para 100.

For example, upon the death of the donor the gift automatically vests in the beneficiary.

Morrison, supra note 1 at paras 44-48.

Wonnacott v Loewen (1990), 44 BCLR (2d) 23 (CA) [Wonnacott]; Anderson v Patton, [1948] 2 DLR 202 (Alta SC (AD)).

(1866), 1 LR P \& D 241.

Ibid at 243 . 
consideration passes; 2. The document has no immediate effect; 3 . The document is revocable; 4 . The position of the deceased and the donee does not immediately change."121

By either test, RRSP and RRIF beneficiary designations are testamentary dispositions. They depend on the registered account holder's death to take effect. They are gratuitous (and this is, in fact, the source of the conundrum this article has sought to tackle). And there is no restriction on the registered account holder's power to change his or her designation.

Applying the above principles, many courts have classified beneficiary designations as testamentary dispositions. These cases come mainly from challenges to beneficiary designations in insurance plans. For instance, in Fontana v. Fontana, the British Columbia Supreme Court reviewed the law of testamentary dispositions and was "led inexorably to the conclusion that a designation of beneficiary is more closely akin to a will than a gift inter vivos and, as such, should be treated in law like a will." ${ }^{122}$ Similarly, in David v. TransAmerica Life Canada, the Ontario Superior Court of Justice treated a life insurance policy as a "testamentary instrument.", 123

Justice Strathy, as he then was, also compared beneficiary designation to testamentary dispositions in Richardson (Estate Trustee of) v. Mew: "It is a solemn act, frequently done privately, and sometimes without the knowledge of the beneficiary. It does not require the consent of the insurer. It is akin to a testamentary disposition. ${ }^{124}$ Justice Strathy's statement harkens back to the rationale for applying the presumption of resulting trust - it places the burden of evidence on the party most likely to possess the evidence. As we noted, and as Justice Strathy stated in the above quote, designated beneficiaries need not even know they were designated. As a result, there is no reason to think they would have superior access to evidence. Further, the private nature of a beneficiary designation has much more in common with a testamentary disposition than an inter vivos gift.

In the context of RRSP beneficiary designations, the plaintiff in Desharnais $v$. Toronto Dominion Bank successfully argued that such a designation was testamentary pursuant to the common law test described in Elliott. ${ }^{125}$ As a result, the beneficiary designation was invalid for not meeting the formal requirements for testamentary dispositions in British Columbia's Wills Act. ${ }^{126}$ While portions of this case were overturned on appeal, the British Columbia Court of Appeal expressly noted there was no challenge to the finding that the designation was testamentary. ${ }^{127}$

Desharnais highlights a potential pitfall with defining all beneficiary designations as testamentary dispositions - provincial acts contain varying formal requirements for testamentary dispositions. In particular, Prince Edward Island and Nova Scotia require

\footnotetext{
121 [1944] 2 DLR 313 at 319 [Elliott].

(1987), 28 CCLI 232 at 236.

2015 ONSC 5192, 11 ETR (4th) 128 at para 60

(2008), 93 OR (3d) 537 (Sup Ct J) at para 27.

2001 BCSC 1695, 42 ETR (2d) 192 at para 39 [Desharnais SC], rev'd in part 2002 BCCA 640, 3 ETR

(3d) 221 [Desharnais CA]. Desharnais SC was followed on this point in 2013 in Easingwood $v$ Easingwood Estate, 2013 BCCA 182, 361 DLR (4th) 304 at para 48.

RSBC 1996, c 489, as repealed by Wills, Estates and Succession Act, SBC 2009, c 13, s 193 [BC Act].
}

Desharnais CA, supra note 125 at para 17. 
testamentary dispositions to be signed and witnessed. ${ }^{128}$ On the other hand, British Columbia specifically removes beneficiary designations from these formal requirements (in postDesharnais legislation). ${ }^{129}$ The remainder of the provinces, including the territories and Quebec, do not require witnesses. ${ }^{130}$

In light of their statutory regimes, the courts in Prince Edward Island and Nova Scotia should take caution in deeming beneficiary designations as testamentary dispositions because this would impose additional formal requirements that banks may be unaware of. More broadly, the variance in the provincial statutory regimes suggests reform should come in the form of amendments to those statutes, rather than from the courts. In other words, provincial legislatures are better situated to coordinate changes in the law of beneficiary designations with laws regarding formal requirements. The following section considers the issue of legislative reform in more depth.

\section{B. Legislative REFORM}

Meddling with the specifics of the presumption of advancement and resulting trust may complicate the law. Indeed, several courts - both domestic ${ }^{131}$ and international ${ }^{132}$ — have refrained from doing so, suggesting the certainty of legislative intervention is preferable. This was the case with presumption of advancement between spouses. The legislatures of Alberta, New Brunswick, Nova Scotia, Prince Edward Island, Newfoundland, and the Northwest Territories have abolished the presumption in favour of comprehensive matrimonial legislation. For example, in Alberta, section 36 of the Matrimonial Property Act abolishes the presumption of advancement between spouses in actions brought under that Act. ${ }^{133}$

Legislation already regulates beneficiaries in the insurance context. Recall that section 666(1) of Alberta's Insurance Act provides that insurance monies go directly to the designated beneficiary, bypassing the estate. ${ }^{134}$ The other common law provinces in Canada have enacted similar regimes. ${ }^{135}$ These laws appear to remove designated beneficiaries of insurance plans from the resulting trust regime. Two provinces - British Columbia and Prince Edward Island - have gone so far as to expand this legislation to RRSPs and RRIFs.

British Columbia ${ }^{136}$ and Prince Edward Island ${ }^{137}$ succession law acts provide that benefits payable to designated beneficiaries from registered investments do not form part of the account holder's estate. Still, there is some uncertainty regarding the scope of these provisions. For instance, the $B C$ Act reads: 
Benefit not part of estate

95 A benefit payable to a designated beneficiary or to a trustee appointed under section 92 under a benefit plan on the death of a participant does not form part of the participant's estate and is not subject to the claims of the participant's creditors. ${ }^{138}$

Whereas, the PEI Act reads:

Plan money not part of estate and free from creditors

9 Where a beneficiary is designated, any benefit payable to the beneficiary is not, from the time of the happening of the event upon which it becomes payable, part of the estate of the participant, and is not subject to the claims of the creditors of the participant. ${ }^{139}$

As can be seen, the PEI Act contains stronger wording regarding the temporal scope of protection, suggesting that from the time of the registered account holder's death, the funds are not part of the estate. In this respect, the PEI Act more closely mirrors protections to insurance beneficiaries under the various provincial regimes reviewed above. ${ }^{140}$ Neither the British Columbia nor the Prince Edward Island provisions have been judicially interpreted.

In McConomy-Wood, the estate beneficiaries argued that legislation similar to that in British Columbia and Prince Edward Island would still be defeated by the presumption of resulting trust. ${ }^{141}$ They submitted that, in accordance with such legislation, the proceeds of the registered account would bypass the estate and go to designated beneficiary. However, that designated beneficiary would then hold the proceeds in trust for the estate beneficiaries, absent contrary intention. Essentially, they argued that there is a distinction between legal and beneficial ownership, and the legislation was not clear on this issue (as it is with matrimonial acts that expressly modify the presumptions). ${ }^{142}$ Justice Herold did not come to a conclusion on this issue in McConomy-Wood, but careful legislative drafting can eliminate this uncertainty in any statutory reform effort.

Legislative reforms should be informed by both matrimonial legislation, which expressly addresses the presumptions of resulting trust and advancement, and laws focussed on beneficiary designations (for example, British Columbia and Prince Edward Island's efforts). For instance, section 36(1) of Alberta's Matrimonial Property Act provides that courts "shall not apply the doctrine of presumption of advancement." married couples seeking to organize their financial affairs. Similarly clear language directing courts not to apply the presumption of resulting trust to beneficiary designations would be useful for registered investors seeking to navigate conflicting judicial decisions.

Supra note 126, s 95.

Supra note 137, s 9 .

See supra note 105.

McConomy-Wood, supra note 59 at paras 50-52, referring to Amherst Crane Rentals Ltd v Perring (2003), 241 DLR (4th) 176 at para 8 (which references the BC Act, supra note 126 and the PEI Act, supra note 137).

McConomy-Wood, ibid at para 49.

Supra note 133. 


\section{Reform in Practice}

Absent legislative action, banks and individuals designating beneficiaries may wish to take matters into their own hands and create a clear evidentiary record establishing intent. The heart of the problem is that it is so obvious that beneficiary designation indicates intent (for example, 97 percent of our sample believed this to be the case). As a result of this obviousness, it is difficult for investors to foresee the need to take such steps. Justice Abella was alert to this issue in her analysis in Pecore, when she wrote: "I think it would come as a surprise to most Canadian parents to learn that in the creation of joint bank accounts with rights of survivorship, there is little evidentiary value in the clear language of what they have voluntarily signed." 144

This caution dovetails with Justice Feldman's reasons in Madsen Estate where she suggested persons designating beneficiaries would need to take the unintuitive step of writing a side letter saying "I really mean it." 145 As a result, it will likely fall to banks to apprise their customers of the law and provide them an opportunity and the appropriate paperwork to establish their intent that their beneficiary should indeed benefit.

\section{CONCLUSION}

Although the presumptions of advancement and resulting trust have attracted a great deal of criticism, courts have, for the most part, retained them due to their policy benefits; they can advance interests such as secure financial management and transactional certainty. Still, in preserving the presumptions, courts are alive to the issue that the presumptions should reflect the default intentions of transferors (that is, what someone giving something to another most likely intends, absent other evidence). Theoretical accounts advanced by academics also place intention front and centre.

On their face, beneficiary designations seem to trigger the presumption of resulting trust as gratuitous transfers. And, in fact, this is what courts in Manitoba, British Columbia, Ontario, and now Alberta have held. However, applying the presumption of resulting trust carries none of the policy benefits that the presumptions have been linked with and may actually interfere with the goals of secure financial management and transactional certainty. More fundamentally, subjecting beneficiary designations to the presumption of resulting trust runs contrary to the intention of most Canadians, a conclusion we establish through both common sense and empirical evidence.

Given this unfortunate development - both in law and policy — we provide several solutions courts and legislative bodies may employ to bring the law back in line with the expectations of investors. Notably, courts may wish to give legal effect to the common sense meaning of beneficiary designation - that it constitutes intent to pass a beneficial interest. Alternatively, provincial legislatures may wish to establish statutory regimes prescribing the role of the presumptions in beneficiary designations. Until such steps are made, investors should consider carefully establishing an evidentiary record to ensure courts can give life to their intentions. Finally, with conflicting decisions at the appellate level, this is an area ripe for Supreme Court of Canada guidance. 


\section{APPENDIX A: \\ EMPIRICAL STUDY}

SURVEY INSTRUCTIONS: We are interested in what people intend when they open certain financial accounts. So please answer the following questions with only your own knowledge and intuition and do not refer to any external services.

1. Imagine you are setting up a Registered Retirement Savings Plan (RRSP). When you set up this plan, you are asked to designate a beneficiary. Imagine you designate your adult son or daughter as beneficiary (if you do not have an adult so nor daughter, imagine you do). Now imagine you write this name down on the appropriate form and the RRSP is opened. By making this choice of beneficiary, what is your intent regarding where the funds will go when you die?

a. It means I want the RRSP to go to my estate.

b. It means I want the RRSP to go the son or daughter I designated.

2. In a sentence, what is an RRSP?

3. In a sentence, what is an estate?

4. Please choose a response below to indicate your level of investment knowledge.

a. I have no financial investment knowledge.

b. I have very little financial investment knowledge.

c. I have some financial investment knowledge.

d. I have a lot of financial investment knowledge.

e. I am a financial investment expert and/or do it as my profession.

5. What is your age? 